\title{
Determination of Physico-Chemical Parameters and Water Quality Index (Wqi) of Chandlodia Lake, Ahmedabad, Gujarat, India
}

\author{
Qureshimatva UM ${ }^{1 *}$, Maurya RR ${ }^{1}$, Gamit SB ${ }^{1}$, Patel RD² and Solanki HA ${ }^{1}$
}

${ }^{1}$ Department of Botany, University School of Sciences, Gujarat University, Ahmedabad 380009, Gujarat, India

${ }^{2}$ Applied BotantCenter, Department of Botany, University School of Sciences, Gujarat University, Ahmedabad 380009, Gujarat, India

\begin{abstract}
The present study was carried outto determine various physico-chemical parameters and water quality indexof the western part of Ahmedabad District to examinethe quality of water for public consumption, recreation and other purposes. This study deals with the influence of environmental factors as well as domestic activities in the water quality in the related area.
\end{abstract}

Keywords: Water quality index; Physico-chemical; Fresh water; Chandlodia lake; Ahmedabad

\section{Introduction}

Water is an essential component of the environment and it sustains life on the earth. All organisms depend on water for their survival [1]. Freshwater bodies are important wetlands located in and around human habitations as they are generally semi natural ecosystems constructed by man in landscape suitable for water stagnation [2]. The quality ofdrinking water is essential for life. Contaminants such as bacteria, viruses, heavy metals, nitratesand salt have polluted water supplies as a result of inadequate treatment and disposal of waste fromhumans, livestock, industrial discharges, domestic discharge and extensive use of limited water resources [3]. There are a number of reported cases of typhoid, diarrhoea and other water borne diseases arising from the consumption of contaminated water. Different works have been reported by many researchers on water quality assessment. Today, contaminated water kills more people than cancer, AIDS, wars, terrorism or accidents [4]. Physico-chemical properties of the water gets varied season wise and in addition, anthropogenic activities such as agriculture, urbanization, domestic sewage, etcin the catchment area resultin the deteriorationof water quality [5]. Temperature, turbidity, nutrients, hardness, alkalinity and dissolved oxygen are some of the important factors that play a vital role for the growth of living organisms in the water body. Water quality indicates the relation of all hydrological properties including physical, chemical and biological properties of the water body. Hence, water quality assessment involves analysis of physico- chemical, biological and microbiological parameters that reflects the biotic and abiotic status of ecosystem [6]. Water quality index (WQI) provides a nominal number that represent overall water quality at a certain location and time, based on several water quality parameters. The objective of water quality index is to turn complex water quality data into detailedinformation useful for public. WQI indicatesthe water quality in terms of index number andoffers a useful presentation of overall quality of water for public or for any intended use as well as in the pollution abatement programmes and in water quality management [7]. The present study deals with the assessment of physico-chemical characteristics of water and on the basis of these variousparameters, water quality index is determined which revealed in the Chandlodia Lake, Ahmedabad, Gujarat, India.

\section{Materials and Methods}

\section{Study area}

Chandlodia lake is the man-made lake located at the Western part of the Ahmedabad city. The lake is bounded by a wooden hedge. Adjacent to the study area, there exists a temple.The waste from the temple including polythene bags and the flowers were directly added into the lake. Beside, solid wastes and contaminated water which are utilized by the local peoples are also released into the lake.

Location: Jagatpur road, Chandlodia, Ahmedabad.

Latitude: $23^{\circ} 05^{\prime} 00.05^{\prime \prime} \mathrm{N}$

Longitude: $72^{\circ} 33^{\prime} 09.43^{\prime \prime} \mathrm{E}$

Areacovered: 22,940 m²

Maintained by: Ahmedabad Urban Development Authority (AUDA), civic body of Ahmedabad Municipal Corporation (AMC).

\section{Methods}

Five different sites were selected for the collection of water samples (Figures 1 and 2). The samples were collected in sterilized polythene bottles of one litter capacity. Monitoring was performed during September 2013 to August 2014 (seasonal monsoon, winter and summer). For unstable parameters such as temperature, electrical conductivity (EC), $\mathrm{pH}$, and dissolved oxygen (DO) were measured at the sampling site. Samples were brought to the laboratory for analysis of other physico-chemical parameters like sodium, total alkalinity, total hardness, calcium, magnesium, chlorides, sulphate, nitrate, phosphate and biochemical oxygen demand (BOD). The parameters were compared according to the standard methods described in the literature [8-10]. The weighted arithmetic index method [11] was used for the calculation of water quality index (WQI) of the water body. Further, quality rating or sub index $\left(\mathrm{q}_{\mathrm{n}}\right)$ was calculated by the following expression.

$$
\mathbf{q}_{\mathrm{n}}=\mathbf{1 0 0}\left[\mathrm{V}_{\mathrm{n}}-\mathrm{V}_{10}\right] /\left[\mathrm{S}_{\mathrm{n}}-\mathrm{V}_{10}\right]
$$

*Corresponding author: Qureshimatva UM, Department of Botany, University School of Sciences, Gujarat University, Ahmedabad-380 009, Gujarat, India, Tel: 07926301341; E-mail: ufmqureshi@yahoo.in

Received April 01, 2015; Accepted April 22, 2015; Published April 26, 2015

Citation: Qureshimatva UM, Maurya RR, Gamit SB, Patel RD, Solanki HA (2015) Determination of Physico-Chemical Parameters and Water Quality Index (Wqi) of Chandlodia Lake, Ahmedabad, Gujarat, India. J Environ Anal Toxicol 5: 288. doi:10.4172/2161-0525.1000288

Copyright: () 2015 Qureshimatva UM et al. This is an open-access article distributed under the terms of the Creative Commons Attribution License, which permits unrestricted use, distribution, and reproduction in any medium, provided the original author and source are credited. 
Citation: Qureshimatva UM, Maurya RR, Gamit SB, Patel RD, Solanki HA (2015) Determination of Physico-Chemical Parameters and Water Quality Index (Wqi) of Chandlodia Lake, Ahmedabad, Gujarat, India. J Environ Anal Toxicol 5: 288. doi:10.4172/2161-0525.1000288

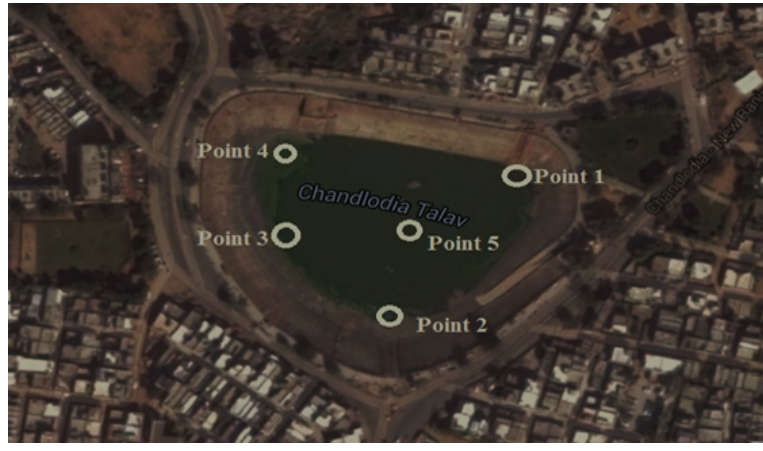

Figure 1: Satellite image of Chandlodia Lake showing the sampling (Source: Google map)s.

Photographs of Chnadlodia Lake showing solid waste and domestic waste releasing site in to the water.

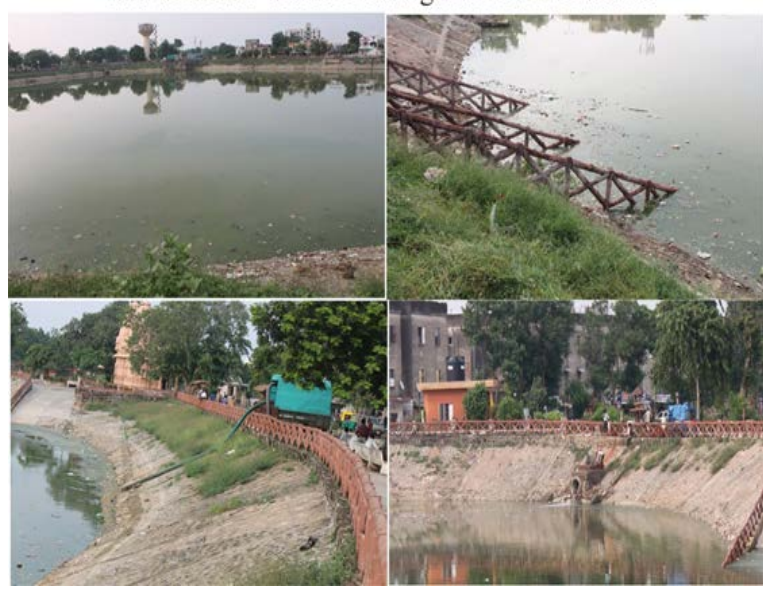

Figure 2: Photographs of Chandlodia Lake showing solid waste and domestic waste releasing site in to the water.

Where: $\mathbf{q}_{\mathbf{n}}=$ Quality rating for the $n^{\text {th }}$ water quality parameter,

$\mathbf{V}_{\mathbf{n}}=$ Estimated value of the $n^{\text {th }}$ water quality parameters of collected sample,

$\mathbf{S}_{\mathbf{n}}=$ Standard permissible value of the $n^{\text {th }}$ water quality parameter,

$\mathbf{V}_{10}=$ Ideal value of the $n^{\text {th }}$ water quality parameter in pure water.

(i.e. 0 for all other parameters except the parameter $\mathrm{pH}$ and Dissolved oxygen ( 7 and $14.6 \mathrm{mg} / \mathrm{L}$ respectively.) (Let there be $n$ water quality parameters and quality rating or sub index $\left(q_{n}\right)$ corresponding to $n^{\text {th }}$ parameter is a number reflecting the relative of this parameter in polluted water with respect to its standard permissible value.)

Unit weight was calculated by a value inversely proportional to the recommended standard value $S_{n}$ of the corresponding parameter.

$\mathbf{W Q I}=\sum \mathbf{q}_{\mathbf{n}} \mathbf{W}_{\mathbf{n}} / \sum \mathbf{W}_{\mathbf{n}}$

Where: $\mathrm{W}_{\mathrm{n}}=$ Unit weight for $\mathrm{n}^{\text {th }}$ water quality parameter,

$\mathrm{S}_{\mathrm{n}}=$ Standard permissible value of the nth water quality parameter,

$\mathrm{K}=$ Constant for proportionality.

The overall WQI was calculated by aggregating the quality rating with the unit weight linearly.

\section{$\mathbf{W Q I}=\sum \mathbf{q}_{\mathbf{n}} \mathbf{W}_{\mathbf{n}} / \sum \mathbf{W}_{\mathbf{n}}$}

Where:

$\mathrm{q}_{\mathrm{n}}=$ Quality rating for the $n^{\text {th }}$ water quality parameter,

$\mathrm{W}_{\mathrm{n}=}$ Unit weight for $n^{\text {th }}$ water quality parameter.

\section{Results and Discussion}

The physico-chemical parameters such as $\mathrm{pH}$, electric conductivity, alkalinity, dissolved oxygen, total dissolve solid, calcium, magnesium, chloride, biological oxygen demand, nitrate and total hardness of water were analysed for the water samples collected from the Chandlodia lake. These parameters were taken at the five points of the lake season wise (monsoon, winter and summer). All parameters with the mean value of the data with standard error were calculated as shown in the Table $1[12,13]$.

\section{Electrical conductivity}

Water capability to transmit electric current is known as electrical conductivity and serves as tool to assess the purity of water [14]. This ability depends on the presence of ions, their total concentration, mobility, valence, relative concentrations and temperature of measurement [15]. The electrical conductivity ranged from 2.15 to 3.47 $\Omega / \mathrm{cm}$. The highest electrical conductivity was reported during winter $3.47 \Omega / \mathrm{cm}$ due to the addition of domestic wastage into the lake [16] and lowest in monsoon $2.15 \Omega / \mathrm{cm}$ because of water dilution by rainy water [17].

\section{Total dissolved solids}

Solids refersto the suspended and dissolved matter in water. They are very useful parameters describing the chemical constituents of the water and can be considered as edaphically relation that contributes to productivity within the water body [18]. The total dissolved solidsin the sampled water ranged from the 1008 to $1224 \mathrm{mg} / \mathrm{L}$. The highest TDS reported during winter season was $1224 \mathrm{mg} / \mathrm{L}$ and lowest TDS reported during summer season was $1008 \mathrm{mg} / \mathrm{L}$ due to the addition of organic matter and solid waste into the lake [19].

\section{pH}

$\mathrm{pH}$ is defined as the intensity of the acidic or basic character of a solution at a given temperature. $\mathrm{pH}$ is the negative logarithm of hydrogen ion concentration $(\mathrm{pH}=-\log [\mathrm{H}+])$. The $\mathrm{pH}$ in water samples range of 7.0 to 7.85 and water and stated that the $\mathrm{pH}$ of water is important for the biotic communities as most of the plant and animal species can survive in narrow range of $\mathrm{pH}$ from slightly acidic to slightly alkaline condition [18]. In study period i.e. September 2013 to August $2014 \mathrm{pH}$ value ranged from 8.2 to 8.9 . The maximum $\mathrm{pH}$ reported during summer was very low due to the water levels and concentration of nutrients in water [20] and minimum was during monsoon due to the dilution of water by addition of rain water [21].

\begin{tabular}{|c|c|}
\hline Water Quality Index Level & Water Quality Status \\
\hline $0-25$ & Excellent water quality \\
\hline $26-50$ & Good water quality \\
\hline $51-75$ & Poor water quality \\
\hline $76-100$ & Very poor water quality \\
\hline$>100$ & Unsuitable for drinking \\
\hline
\end{tabular}

Table 1: Water Quality Index (WQI) and its status according to Chaterjee and Raziuddin [12] and Thakor et al. [13] 


\section{Alkalinity}

The alkalinity of surface water is primarily a function of carbonate, hydroxide content and also includes the contributions from borates, phosphates, silicates and other bases. Alkalinity is a measure of capacity of water to neutralize a strong acid [22]. The alkalinity in the water samples ranged from 204 to $224 \mathrm{mg} / \mathrm{L}$. The highest alkalinity recorded during winter was $224 \mathrm{mg} / \mathrm{L}$ due to high nutrients in water [4] and lowest recorded during monsoon was $204 \mathrm{mg} / \mathrm{L}$ due to dilution of water by addition into lake water $[16,17]$.

\section{Total hardness}

The total hardness of water is not a specific constituent but is a variable and complex mixture of cations and anions. Principally the water hardness are changed by ions such as calcium and magnesium. The total hardness from the water samples at Chandlodia Lake ranged between 310 to $348 \mathrm{mg} / \mathrm{L}$. The highest amount of total hardness in the water was recorded during monsoon was $348 \mathrm{mg} / \mathrm{L}$ due to presence of high content of calcium and magnesium in addition to sulphate and nitrate in the sewage waste added during monsoon [23]. The lowest amount of total hardness was recorded during winter season due to low concentration of calcium and magnesium [24].

\section{Calcium}

Calcium is most abundant ions in fresh water and is important in shell construction, bone building and plant precipitation of lime. The analysis of calcium revealed a ranged between 72 to $94 \mathrm{mg} / \mathrm{L}$. The highest amount of calcium recorded in water samples during monsoon season was $94 \mathrm{mg} / \mathrm{L}$ by the addition of sewage waste along with rain water and responsible for the increase in amount of calcium [25]. The lowest amount of calcium in water was recorded during winter season due to calcium absorbed by the large number of organisms for shell construction, bone building and plant precipitation of lime [17].

\section{Magnesium}

Magnesium is often associated with calcium in all kinds of waters, but its concentration remains generally lower than the calcium. Magnesium is essential for chlorophyll growth and acts as a limiting factor for the growth of phytoplankton [17]. The amount of magnesium recorded in the water ranged between 36 to $41 \mathrm{mg} / \mathrm{L}$. The highest amount of magnesium in the water samples was recorded during monsoon season $41 \mathrm{mg} / \mathrm{L}$ as it is associated with calcium in all water types and during monsoon,calcium was higher in monsoon season.The lowest value was recorded during summer season due to themagnesium essentiality for chlorophyll bearing plant for photosynthesis [23].

\section{Dissolved oxygen}

The higher value of dissolved oxygen indicates good aquatic life. The amount of dissolved oxygen of Chandlodia Lake watersamples ranged between 3.13 to $5.89 \mathrm{mg} / \mathrm{L}$. The highest amount recorded during monsoon season was $5.41 \mathrm{mg} / \mathrm{Ldue}$ to the turbulence of water facilitating the diffusion of atmospheric oxygen and the increased solubility of oxygen at lower temperature [2]. The lowest dissolved recorded during summer season was $3.13 \mathrm{mg} / \mathrm{L}$ due to the high temperature and addition of sewage and other waste which can be responsible for low value of dissolved oxygen [17].

\section{Chloride}

The chloride in drinking water originates from natural sources, sewage and industrial effluents, urban runoff containing de-icing salt and saline intrusion [17]. A chloride concentration in Chandlodia lake was noticed between 98 to $103 \mathrm{mg} / \mathrm{L}$. The highest chloride reported in winter was $79 \mathrm{mg} / \mathrm{L}$ due to frequent run-off loaded with contaminated water from the surrounding slum area and evaporation of water [25]. The lowest value of chloride recorded during monsoon season was 98 $\mathrm{mg} / \mathrm{L}$ due to the dilution of lake water by rain [26].

\section{Nitrate}

Nitrates are contributes to freshwater through discharge of sewage and industrial wastes and run off from agricultural fields [17]. The highest amount of nitrate concentration was known to support the formation of blooms [4]. The amount of nitrate recorded in the water of Chandlodia Lake ranged from 6.3 to $7.9 \mathrm{mg} / \mathrm{L}$. The highest amount of nitrate was recorded during winter season was $7.9 \mathrm{mg} / \mathrm{L}$ because of high vegetation during winter which supported the growth of plankton [27]. The lowest amount of nitrate in water was recorded during summer season was 7.5 $\mathrm{mg} / \mathrm{L}$ by the utilization by plankton and aquatic plants [25].

\section{Biochemical oxygen demand}

The biochemical oxygen demand may be defined as the oxygen required for the microorganism to performed biological decomposition of dissolved solids or organic matter in the wastewater under aerobic conditions [28]. The biochemical oxygen demand reported from water samples at Chandlodia Lake was rangedbetween 1.78 to $3.22 \mathrm{mg} / \mathrm{L}$. The highest demand of oxygen in the water was recorded during monsoon season was $3.22 \mathrm{mg} / \mathrm{L}$ due to the possible addition of high amount of waste along with rain water from the surrounding and addition of organic waste in lake by certain human activities which also be responsible for the increase in BOD [29,30]. The lowest demand was recorded during monsoon season was $1.78 \mathrm{mg} / \mathrm{L}$ due to less vegetation [21]. WQI of Chandlodia Lakewas established from various physicochemical parameters in three seasons (monsoon, winter and summer) from September 2013 to August 2014. The values of various physicochemical parameters for calculation of water quality index are presented in Table 2. Season wise WQIcalculations are presented in the Tables 3-5. The WQI obtained for the water body in different seasons of study period i.e., monsoon season, winter season and summer season are $97.1624,109.6275$ and 84.1007 respectively, which indicate that water is not suitable for drinking due to high pollution level during winter season when compared to the monsoon and summer seasons.

The water is not used for public consumption due to high WQI and high pollution level. Water purification system must be installed to purify the water body as other alternatives, for domestic usage is not recommended by the civic body. The purification requires civic body initiative to clean up. This reason on a view that concerned agency had already installed three water purification systems in the city.

\section{Conclusion}

Some of the samples have total dissolved solids, $\mathrm{pH}$, alkalinity, total hardness, magnesium, calcium anddissolved oxygen valuesexceeding the permissible limits as prescribed by Indian standards. We noticed parameters such as electrical conductivity, chloride, nitrate and biological oxygen demand values are within permissible limits. The competed WQI indicates that the water quality is poor and not totally safe for human consumption due to presence of high level of pollutants. The water is not used for public consumption and rerceartion due to lack of water purification. This study showed that the water quality of Chandlodia Lake remain as it is than it will destroyed the ecosystem of the lake. The government bodu such as AUDA, AMC and other civic organisation should take the action against releasing of domestic waste directly into the lake or installed a water purification system. 
Citation: Qureshimatva UM, Maurya RR, Gamit SB, Patel RD, Solanki HA (2015) Determination of Physico-Chemical Parameters and Water Quality Index (Wqi) of Chandlodia Lake, Ahmedabad, Gujarat, India. J Environ Anal Toxicol 5: 288. doi:10.4172/2161-0525.1000288

Page 4 of 6

\section{Average with standard error values of physico-chemical parameters of water samples collected at Chandlodia Lake.}

\begin{tabular}{|c|c|c|c|c|}
\hline \multicolumn{5}{|c|}{ Average with standard error values of physico-chemical parameters of water samples collected at Chandlodia Lake. } \\
\hline \multirow{2}{*}{ Sr. No. } & \multirow{2}{*}{ Parameters } & \multicolumn{3}{|c|}{ Year 2013-14 } \\
\hline & & Monsoon & Winter & Summer \\
\hline 1 & Electrical conductivity $(\Omega / \mathrm{cm})$ & $3.47 \pm 0.18$ & $3.14 \pm 0.77$ & $2.15 \pm 0.02$ \\
\hline 2 & Total Dissolve Solid (mg/L) & $1224 \pm 42.79$ & $1008 \pm 14.88$ & $1142 \pm 12.66$ \\
\hline 3 & $\mathrm{pH}$ & $8.6 \pm 0.17$ & $8.9 \pm 0.50$ & $8.2 \pm 0.22$ \\
\hline 4 & Alkalinity $(\mathrm{mg} / \mathrm{L})$ & $224 \pm 9.23$ & $214 \pm 3.36$ & $204 \pm 8.44$ \\
\hline 5 & Total Hardness (mg/L) & $348 \pm 19.82$ & $310 \pm 11.2$ & $335 \pm 14.22$ \\
\hline 6 & Calcium (mg/L) & $94 \pm 0.47$ & $72 \pm 0.12$ & $80 \pm 0.62$ \\
\hline 7 & Magnesium (mg/L) & $41 \pm 0.39$ & $37 \pm 0.43$ & $36 \pm 0.87$ \\
\hline 8 & Dissolved Oxygen (mg/L) & $5.89 \pm 0.36$ & $3.29 \pm 0.67$ & $3.13 \pm 0.44$ \\
\hline 9 & Chloride (mg/L) & $104 \pm 3.4$ & $108 \pm 4.9$ & $135 \pm 4.9$ \\
\hline 10 & Nitrate $(\mathrm{mg} / \mathrm{L})$ & $7.2 \pm 0.29$ & $7.9 \pm 0.83$ & $6.3 \pm 0.34$ \\
\hline 11 & Biochemical Oxygen Demand (mg/L) & $3.22 \pm 0.79$ & $2.14 \pm 0.27$ & $1.78 \pm 0.24$ \\
\hline
\end{tabular}

Table 2: Average with standard error values of physico-chemical parameters of water samples collected at Chandlodia Lake.

\begin{tabular}{|c|c|c|c|c|c|c|c|}
\hline \multicolumn{8}{|c|}{ Calculation of WQI of water samples in monsoon season of Chandlodia Lake } \\
\hline S.No & Parameter & $\begin{array}{l}\text { Observed } \\
\text { Value (Vn) }\end{array}$ & $\begin{array}{l}\text { Standard } \\
\text { Values (Sn) }\end{array}$ & Ideal Value (V10) & Unit Weight (WN) & Quality Rating (Qn) & WnQn \\
\hline 1 & Electrical conductivity $(\Omega / \mathrm{cm})$ & 3.47 & 300 & 0 & 0.371 & 1.15 & 0.42 \\
\hline 2 & Total Dissolve Solid (mg/L) & 1224 & 500 & 0 & 0.0037 & 244.8 & 0.90 \\
\hline 3 & $\mathrm{pH}$ & 8.6 & 7.5 & 7 & 0.219 & 320 & 70.08 \\
\hline 4 & Alkalinity (mg/L) & 224 & 120 & 0 & 0.0155 & 186.66 & 2.89 \\
\hline 5 & Tatal Hardness (mg/L) & 348 & 300 & 0 & 0.0062 & 116 & 0.71 \\
\hline 6 & Calcium (mg/L) & 94 & 75 & 0 & 0.025 & 125.33 & 3.13 \\
\hline 7 & Magnesium (mg/L) & 41 & 30 & 0 & 0.061 & 136.66 & 8.33 \\
\hline 8 & Dissolved Oxygen (mg/L) & 5.89 & 5 & 14.6 & 0.3723 & 90.72 & 33.77 \\
\hline 9 & Chloride (mg/L) & 104 & 250 & 0 & 0.0074 & 41.6 & 0.30 \\
\hline 10 & Nitrate (mg/L) & 7.2 & 45 & 0 & 0.0412 & 16 & 0.65 \\
\hline \multirow[t]{2}{*}{11} & $\begin{array}{l}\text { Biochemical Qxygen Demand } \\
(\mathrm{mg} / \mathrm{L})\end{array}$ & 3.22 & 5 & 0 & 0.3723 & 64.4 & 23.97 \\
\hline & & & & & $\Sigma W_{n}=1.4946$ & $\Sigma Q_{n}=1343.3525$ & $\Sigma W_{n} Q_{n}=145.2190454$ \\
\hline \multicolumn{8}{|c|}{ WQI=97.16248187 } \\
\hline
\end{tabular}

Table 3: Calculation of WQI of water samples in monsoon season of Chandlodia Lake.

\begin{tabular}{|c|c|c|c|c|c|c|c|}
\hline \multicolumn{8}{|c|}{ Calculation of WQI of water samples in winter season of Chandlodia Lake } \\
\hline Sr.No & Parameter & $\begin{array}{c}\text { Observed Value } \\
(\mathbf{V n})\end{array}$ & $\begin{array}{c}\text { Standard Valus } \\
\text { (Sn) }\end{array}$ & Ideal Value (V10) & Unit Weight (WN) & Quality Rating (Qn) & WnQn \\
\hline 1 & Electrical conductivity $(\Omega / \mathrm{cm})$ & 3.14 & 300 & 0 & 0.371 & 1.04 & 0.38 \\
\hline 2 & Total Dissolve Solid (mg/L) & 1008 & 500 & 0 & 0.0037 & 201.6 & 0.74 \\
\hline 3 & $\mathrm{pH}$ & 8.9 & 7.5 & 7 & 0.219 & 380 & 83.22 \\
\hline 4 & Alkalinity (mg/L) & 214 & 120 & 0 & 0.0155 & 178.33 & 2.76 \\
\hline 5 & Tatal Hardness (mg/L) & 310 & 300 & 0 & 0.0062 & 103.33 & 0.64 \\
\hline 6 & Calcium (mg/L) & 72 & 75 & 0 & 0.025 & 96 & 2.4 \\
\hline 7 & Magnesium (mg/L) & 37 & 30 & 0 & 0.061 & 123.33 & 7.52 \\
\hline 8 & Dissolved Oxygen (mg/L) & 3.29 & 5 & 14.6 & 0.3723 & 117.81 & 43.86 \\
\hline 9 & Chloride (mg/L) & 108 & 250 & 0 & 0.0074 & 43.2 & 0.31 \\
\hline 10 & Nitrate (mg/L) & 7.9 & 45 & 0 & 0.0412 & 17.55 & 0.72 \\
\hline \multirow[t]{2}{*}{11} & $\begin{array}{l}\text { Biochemical Qxygen Demand } \\
(\mathrm{mg} / \mathrm{L})\end{array}$ & 2.14 & 5 & 0 & 0.3723 & 42.8 & 15.93 \\
\hline & & & & & $\Sigma W_{n}=1.4946$ & $\Sigma Q_{n}=1305.01422$ & $\Sigma W_{n} Q_{n}=158.5214026$ \\
\hline
\end{tabular}

Table 4: Calculation of WQI of water samples in winter season of Chandlodia Lake. 
Citation: Qureshimatva UM, Maurya RR, Gamit SB, Patel RD, Solanki HA (2015) Determination of Physico-Chemical Parameters and Water Quality Index (Wqi) of Chandlodia Lake, Ahmedabad, Gujarat, India. J Environ Anal Toxicol 5: 288. doi:10.4172/2161-0525.1000288

Page 5 of 6

\begin{tabular}{|c|c|c|c|c|c|c|c|}
\hline \multicolumn{8}{|c|}{ Calculation of WQI of water samples in summer season of Chandlodia Lake. } \\
\hline Sr.No & Parameter & $\begin{array}{l}\text { Observed Value } \\
(\mathrm{Vn})\end{array}$ & $\begin{array}{c}\text { Standard Valus } \\
\text { (Sn) }\end{array}$ & $\begin{array}{l}\text { Ideal Value } \\
\quad \text { (V10) }\end{array}$ & Unit Weight (WN) & Quality Rating (Qn) & WnQn \\
\hline 1 & Electrical conductivity $(\Omega / \mathrm{cm})$ & 2.15 & 300 & 0 & 0.371 & 0.71 & 0.26 \\
\hline 2 & Total Dissolve Solid (mg/L) & 1142 & 500 & 0 & 0.0037 & 228.4 & 0.84 \\
\hline 3 & $\mathrm{pH}$ & 8.2 & 7.5 & 7 & 0.219 & 240 & 52.56 \\
\hline 4 & Alkalinity (mg/L) & 204 & 120 & 0 & 0.0155 & 170 & 2.635 \\
\hline 5 & Tatal Hardness (mg/L) & 335 & 300 & 0 & 0.0062 & 111.66 & 0.69 \\
\hline 6 & Calcium (mg/L) & 80 & 75 & 0 & 0.025 & 106.66 & 2.66 \\
\hline 7 & Magnesium (mg/L) & 36 & 30 & 0 & 0.061 & 120 & 7.32 \\
\hline 8 & Dissolved Oxygen (mg/L) & 3.13 & 5 & 14.6 & 0.3723 & 119.47 & 44.48 \\
\hline 9 & Chloride (mg/L) & 135 & 250 & 0 & 0.0074 & 54 & 0.39 \\
\hline 10 & Nitrate $(\mathrm{mg} / \mathrm{L})$ & 6.3 & 45 & 0 & 0.0412 & 14 & 0.57 \\
\hline \multirow[t]{2}{*}{11} & $\begin{array}{l}\text { Biochemical Qxygen Demand } \\
(\mathrm{mg} / \mathrm{L})\end{array}$ & 1.78 & 5 & 0 & 0.3723 & 35.6 & 13.25 \\
\hline & & & & & $\Sigma W_{n}=1.4946$ & $\Sigma Q_{n}=1200.53$ & $\Sigma W_{n} Q_{n}=125.697$ \\
\hline
\end{tabular}

Table 5: Calculation of WQI of water samples in winter season of Chandlodia Lake.

\section{Acknowledgement}

Mr. Qureshimatva Umerfaruq M. is supported by the University Grant Commission as Junior Research Fellow under Mualana Azad National Fellowship scheme.

\section{References}

1. Smitha PG, Byrappa K, Ramaswamy SN (2007) Physico-chemical characteristics of water samples of Bantwal Taluk, South-Western Karnataka, India. J Environ Biol 28: 591-595.

2. Yadav P, Yadav AK, Khare PK (2013). Physico-Chemical characteristics of a freshwater pond of Orai, U.P., Central India. Octa Journal of Biosciences 1: 177-184.

3. Onwughara NI, Ajiwe VIE, Nnabuenyi HO (2013) Physico-chemical studies of water from selected boreholes in Umuahia North Local Government Area, in Abia State, Nigeria. International Journal of Pure \& Applied Bioscience 1: $34-44$

4. Uduma AU (2014) Physico-chemical analysis of the quality of sachet water consumed in Kano metropolis. American Journal of Environment, Energy and Power Research 2: 1-10.

5. Verma PU, Purohit AR, Patel NJ (2012) Pollution status of Chandlodia lake located in Ahmedabad Gujarat. International Journal of Engineering Research and Applications 2: 1600-1610.

6. Smitha AD, Shivashankar $P$ (2013) Physico-chemical analysis of the freshwater at river Kapila, Nanjangudu industrial area, Mysore, India. International Research Journal of Environment Sciences 2: 59-65.

7. Kotadiya NG, Acharya CA, Radadia BB, Solanki HA (2013) Determination of Water Quality Index and suitability of a rural freshwater body in Ghuma village, District Ahmedabad, Gujarat. Life Sciences Leaflets 2: 68-67.

8. Lenore Clesceri S APHA (1989) Standard Methods for the Examination of water and waste water (17thedn.) APHA, AWWA, WPCE, Washington DC

9. World Health Organization (W.H.O.) (1998) Guideline for drinking water quality Health criteria and other supportingInformation (2ndedn.) Geneva, 2: 231 -270.

10. Botkin DB, Keller EA (1995) Environmental Science: Earth as a living plane, Water Pollution and Treatment, John Wiley and Sons

11. Brown RM, Mccleiland NJ, Deiniger RA, O' Connor MFA (1972) Wate quality index - crossing the physical barrier. In: Jenkis SH (ed.) International Conference on Water Pollution Research, Jerusalem. 6: 787-797.

12. Chaterjee $C$ and Raziuddin M (2002) Determination of water quality index (WQI) of a degraded river in Asanol Industrial area, Raniganj, Burdwan, West Bengal. Nature Environment and Pollution Technology 2: 181-189.
13. Thakor FJ, Bhoi DK, Dabhi HR, Pandya SN, Chauhan NB (2011) Water Quality Index (WQI) of Pariyej lake District Kheda, Gujarat. Current World Environment 6: 225-231.

14. Murugesan A, Ramu A and Kannan N (2006) Water quality assessment from Uthamapalayam municipality in Theni District, Tamil Nadu, India. Pollution Research 25: 163-166.

15. Shinde SE, Pathan SA, Raut KS, Sonawane DL (2011) Studies on the Physicochemical parameters and correlation coefficient of Harsool-savangi Dam, District Aurangabad, India. Middle-East Journal of Scientific Research 8: 544-554.

16. Verma PU, Chandawat D, Gupta U, Solanki HA (2012) Water quality analysis of an organically polluted lake by investigating different physical and chemical parameters. International Journal of Research in Chemistry and Environment 2: 105-111.

17. Solanki HA (2012) Status of soils and water reservoirs near industrial areas of Baroda: pollution and soil - water chemistry. Lap Lambert Academic Publishing, Germany, ISBN 376.

18. Goher MEM (2002) Chemical studies on the precipitation and dissolution of some chemical element in lake Qarun, Ph.D. Thesis faculty of sciences, AlAzhar University, Egypt.

19. Moss B (1973) The influence of environmental factors of the distribution of fresh water algae on experimental study. The role of $\mathrm{pH}$, carbon dioxide and bicarbonate system. Journal of Ecology 6: 157.

20. Narayana J, Puttaiah ET, Basavaraja D (2008) Water quality characteristics of Anjanapura reservoir near Shikaripur, District Shimoga, Karnataka. Journal of Aquatic Biology 23: 59-63.

21. Reddy VK, Prasad KL, Swamy M , Reddy R (2009) Physico-chemica parameters of Pakhal lake of Warangal District Andhra Pradesh, India. Journal of Aquatic Biology 24: 77-80.

22. Wetzel RG (1983) Limnology, Second Edition, edited by Wetzel LG, Michigan State University, CRS College Publishing Philadelphia, New York.

23. Pawar SK, Pulle JS (2005) Studies on physico-chemical parameters in Pethwadaj dam, Nanded District in Maharashtra, India. Journal of Aquatic Biology 20: 123-128.

24. Salve BS, Hiware CJ (2006) Studies on water quality of Wanparakalpa Reservoir, Nagapur, near Parli Vaijnath, District Beed, and Marathwada region. Journal of Aquatic Biology 21: 113-117.

25. Verma PU, Chandawat D, Solanki HA (2010) Study of water quality of Hamirsar lake - Bhuj. International Journal of Bioscience Reporter 8: 145-153.

26. Shastry CA, Aboo KM, Bhatia HL, Rao AV (1970) Pollution of upper lake and its effect on Bhopal water supply. Journal of Environmental Health 12: 218-238. 
Citation: Qureshimatva UM, Maurya RR, Gamit SB, Patel RD, Solanki HA (2015) Determination of Physico-Chemical Parameters and Water Quality Index (Wqi) of Chandlodia Lake, Ahmedabad, Gujarat, India. J Environ Anal Toxicol 5: 288. doi:10.4172/2161-0525.1000288

Page 6 of 6

27. Pandit BR, Solanki HA (2004) Drinking water quality and techniques for recharging urban water system for the industrial city of Gujarat, India. In: Innovative Modelling of Urban Water Systems, Monograph No. 12 Canada, Chapter - 33, ISBN.

28. Solanki HA, Pandit BR (2006) Trophic status of lentic waters of ponds water of Vadodara, Gujarat, India. International Journal of Bioscience Reporter 4: 191-198.
29. Solanki HA (2007) Ecological studies of phytoplankton of Mini Mahi River Gujarat, India. Vidya 2: 47-57.

30. Solanki HA (2001) Study on pollution of soils and water reservoirs near industrial areas of Baroda. Ph.D. Thesis submitted to Bhavnagar University, Bhavnagar. 